\title{
MINEROGRAPHIC STUDY OF SOME OF THE SULPHIDE ORES FROM INGALDHAL, CHITALDURG DISTRICT, MYSORE STATE
}

\author{
By A. M. Pathan and C. Naganna \\ (Department of Geology, Bangalore University, Bangalore) \\ Received March 28, 1970 \\ (Communicated by Dr. B. P. Radhakrishna, F.A.sc.)
}

\begin{abstract}
Minerographic study of the ore samples collected from Ingaldhal copper mines shows that the ores are largely massive, banded and disseminated in structure. Pyrite, arsenopyrite, cobaltite, sphalerite, pyrrhotite, galena and chalcopyrite as primary minerals and pyrrhotite, chalcopyrite, stromyerite, bornite, chalcocite and tennantite as secondary minerals are present. The ores exhibit inclusion, panidiomorphic, mutual boundary, exsolution and replacement textures. From the mineralogical assemblage and the textures it is inferred that the ore deposits were formed in the temperature range of $350^{\circ}-500^{\circ} \mathrm{C}$.
\end{abstract}

\section{INTRODUCTION}

OCCURRENCE of sulphide ores in Ingaldhal (lat. $14^{\circ} 12^{\prime}$, long. $76^{\circ} 27^{\prime}$ ) has been known for a long time. A brief account of the exploratory work done in this area is given by Radhakrishna (1967). Though sulphide ores occur in different parts of Mysore State, a systematic study of these has not so far been attempted. As a part of the minerographic study of the sulphide ores of the Mysore State, the authors have completed the ore microscopic studies of the sulphide ores collected from adit 2 and 3 of Ingaldhal copper mines. The result of this study is reported in this paper.

Mode of Occurrence.-The sulphide ores are seen confined to narrow brecciated and sheared zones of trap rocks with intercalations of chert bands. Mineralisation in some places appears to move across the sheared zone increasing the thickness of mineralised zone to a width of about a metre. Where the mineralised zone has greater width the adjoining trap rocks are also impregnated with sulphide ore minerals. The sulphide ores occur as bands, veins and veinlets. 
The mineralised zones occurring in schistose trap appear to swell and pinch giving an en-echelon pattern of ore distribution. The epidiorite trap ranges in colour from ash-grey to green and varies in texture from coarse-grained to almost glassy.

Description of ores under the microscope.-The ores from Ingaldhal can be grouped into four categories namely: the massive ore, the brecciated ore, the disseminated ore and the banded ore.

The massive ore is made up mostly of chalcopyrite; some massive ores contain an assemblage of three to four minerals, namely chalcopyrite, pyrrhotite, pyrite and sphalerite. The brecciated ore is differentiated from the massive ore by the presence of angular fragments of gangue minerals. The disseminated ore is largely made up of euhedral crystals of pyrites. In the banded ore allotriomorphic grains of pyrites occur as continuous streaks alternating with chert bands. The microscopic descriptions of the ore minerals are summarized in Table $I$.

Textures.-Sulphides under study are characterised to a great extent by massive and banded structures. Pyrite and arsenopyrite show banded structure. Chalcopyrite and sphalerite show massive structure. Besides these, the presence of the following textures have been established.

Inclusion texture.-This texture is best shown by the inclusion of euhedral to rounded crystals of pyrite, arsenopyrite and cobaltite within chalcopyrite. Few anhedral grains of pyrrhotite are seen enclosed in sphalerite and also chalocpyrite (Plate V, Fig. $1 a, b$ ).

Panidiomorphic texture.-This texture is very well developed by pyrite and arsenopyrite. Even in hand-specimen these minerals show euhedrism. Cubes of pyrite range in size from $0.25 \mathrm{~cm}$. to $1.3 \mathrm{~cm}$. and arsenopyrite from one $\mathrm{mm}$. to a few $\mathrm{mm}$. These minerals are embedded in chert and trap rocks (Plate V, Fig. $2 a, b$ ).

Mutual boundary texture.-This texture is very well observed in chalcopyrite and pyrrhotite. Contacts of both the minerals are smooth and not ragged; protuberances of one mineral in another is very well seen. All these factors are evidences of simultaneous formation of two minerals producing mutual boundary texture (Plate V Fig. 3).

Exsolution texture.-This texture is observed between sphaleritechalcopyrite, sphalerite-pyrrhotite and between chalcopyrite-stromyerite. 


\section{TABLE I}

Description of individual minerals as identified under ore microscope

\begin{tabular}{|c|c|c|c|c|c|}
\hline Mineral & & Description & $\begin{array}{c}\text { Textural } \\
\text { descriptions }\end{array}$ & $\begin{array}{c}\text { Micro- } \\
\text { hardness } \\
\text { in } \\
\mathrm{kg} \cdot / \mathrm{mm} .^{2}\end{array}$ & Etch test \\
\hline Pyrite & $\cdots$ & $\begin{array}{l}\text { White in colour and iso. } \\
\text { tropic }\end{array}$ & $\begin{array}{l}\text { Occurs in two forms. (i) Banded } \\
\text { and (ii) disseminated. Banded } \\
\text { pyrite is anhedral granular aggre- } \\
\text { gate and disseminated pyrite is } \\
\text { coarse and fine euhedral crystals. } \\
\text { Some grains are seen enclosed in } \\
\text { chalcopyrite and pyrrhotite with } \\
\text { corroded outlines. }\end{array}$ & 1023 & $\begin{array}{l}\text { Except } \mathrm{HNO}_{3} \text { negative to } \\
\text { all other reagents. }\end{array}$ \\
\hline Chalcopyrite & .. & $\begin{array}{l}\text { Yellow in colour with } \\
\text { slight cream coloura- } \\
\text { tion. It is non-pleo. } \\
\text { chroic and twinning is } \\
\text { sometimes observed. } \\
\text { Anisotropism is weak } \\
\text { to moderate. }\end{array}$ & $\begin{array}{l}\text { Majority of the minerals are massive } \\
\text { and anhedral-also occurs as dis- } \\
\text { creet grains, irregular in shape fill- } \\
\text { ing the spaces between quartz. } \\
\text { Occasionally it fills the openings } \\
\text { in pyrite. It encloses pyrite, } \\
\text { arsenopyrite and cobaltite. }\end{array}$ & 153 & $\begin{array}{l}\mathrm{HNO}_{3} \text { tarnishes very } \\
\text { slowly, aquaregia stains } \\
\text { brown. Negative to all } \\
\text { other reagents. }\end{array}$ \\
\hline Arsenopyrite & $\ldots$ & $\begin{array}{l}\text { White in colour; aniso- } \\
\text { tropism weak. }\end{array}$ & $\begin{array}{l}\text { It is limited in occurrence, It either } \\
\text { forms anhedra? wedge-shaped } \\
\text { crystal forming bands in chert and } \\
\text { schist or it occurs as massive } \\
\text { aggregate of coarse subhedral- } \\
\text { anhedral grains. The euhedral } \\
\text { crystals are short and stumpy. At } \\
\text { many places minsral shows frac- } \\
\text { turing healed by quartz. }\end{array}$ & 977 & $\begin{array}{l}\mathrm{HNO}_{3} \text { slow effervescence. } \\
\text { Positive to } \mathrm{HgCl}_{2} \text {. } \\
\text { Negative to other re } \\
\text { agents. }\end{array}$ \\
\hline Sphalerite & .. & $\begin{array}{l}\text { Grey in colour and iso- } \\
\text { tropic }\end{array}$ & $\begin{array}{l}\text { Occurs as anhedral granular aggre- } \\
\text { gate in chert with inclusions of } \\
\text { pyrrhotite. }\end{array}$ & $\cdots$ & 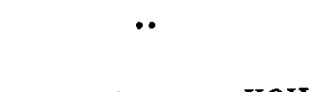 \\
\hline Pyrrhotite & $\cdots$ & $\begin{array}{l}\text { Cream-culoured, non- } \\
\text { pleochroic, exhibits } \\
\text { strong anisotropism. }\end{array}$ & $\begin{array}{l}\text { Mineral occurs as massive anhedral } \\
\text { granular aggregate in association } \\
\text { with chalcopyrite and sphalerite. } \\
\text { It shows numerous inclusions of } \\
\text { angular fragments of country rock. }\end{array}$ & 228 & $\begin{array}{l}\mathrm{HNO}_{3} \text { brown, } \mathrm{KOH} \\
\text { brown and negative to } \\
\text { other reagents. }\end{array}$ \\
\hline Galena & $\cdots$ & $\begin{array}{l}\text { White in colour and iso- } \\
\text { tropic. }\end{array}$ & $\begin{array}{l}\text { Occurs as anhedral grains with per- } \\
\text { fect } 3 \text { sets of cleavages forming } \\
\text { triangular pits. }\end{array}$ & . & $\begin{array}{l}\mathrm{HCl} \text { tarnishes, } \mathrm{FeCl}_{3} \\
\text { tamishes and negative } \\
\text { to other reagents. }\end{array}$ \\
\hline Cobaltite & .. & $\begin{array}{l}\text { Pinkish in colour and iso- } \\
\text { tropic }\end{array}$ & $\begin{array}{l}\text { Occurs as inclusion in chalcopyrite. } \\
\text { It is anhedral to euhedral with } \\
\text { corroded borders. }\end{array}$ & 1020 & Negative to all reagents. \\
\hline Stromyerite & $\cdots$ & $\begin{array}{l}\text { Pink ish-violet in colour. } \\
\text { Reflection pleochroism } \\
\text { is weak in pink colours. } \\
\text { Anisotropism moderate. }\end{array}$ & $\begin{array}{l}\text { It occurs in chalcopyrite as wedges } \\
\text { and lenses which show variation in } \\
\text { size. }\end{array}$ & 70 & $\begin{array}{l}\mathrm{HNO}_{3} \text { stains brown, } \\
\mathrm{HCl} \text { fumes, } \mathrm{FeCl} l_{3} \\
\text { stains irid, } \mathrm{KOH} \text { nega- } \\
\text { tive, } \mathrm{HgCl}_{2} \text { stains and } \\
\text { aquaregia turns grey. }\end{array}$ \\
\hline Chalcocite & $\cdots$ & $\begin{array}{l}\text { B luish in colour, aniso- } \\
\text { tropism moderate. }\end{array}$ & $\begin{array}{l}\text { Occurs as secondary mineral along } \\
\text { fractures and grain boundaries rt- } \\
\text { placing chalcopyrite. }\end{array}$ & $\bullet$ & - \\
\hline $\begin{array}{l}\text { Bornite } \\
\text { Ten nantite (?) }\end{array}$ & $\ddot{. .}$ & $\begin{array}{l}\text { Pinkish-brown, isotropic. } \\
\text { Bluish-green, isotropic }\end{array}$ & $\begin{array}{l}\text { do. } \\
\text { Occurs as secondary minerals replac- } \\
\text { ing arsenopyrite }\end{array}$ & $\ddot{\circ}$ & $\because$ \\
\hline
\end{tabular}


In the case of sphalerite-chalcopyrite combination string-like blebs or globules of chalcopyrite occur in sphalerite. These globules and blebs are very small in size and in some cases many parallel strings are noticed (Plate V, Fig. 4). Minute globules and small wedges of pyrrhotite are seen distributed or dispersed throughout sphalerite, but crystallographic direction is not apparent.

In chalcopyrite-stromyerite, stromyerite occurs in chalcopyrite as wedges and lenses. These wedges range in size from one $\mathrm{mm}$. to one $\mathrm{cm}$. Commonly stromyerite shows crenulated boundaries to chalcopyrite, but boundary between the two is continuous. These wedges and lenses become so wide that they can no longer be termed as lamellae.

Replacement texture.-This texture is very well seen in almost all the minerals. In most of the cases replacement appears to have taken place along grain boundaries, cleavages, and original bedding planes. Some of the specimens particularly those containing pyrite show beautiful banding even in hand-specimen and the banding here resembles banding noticed in banded ferruginous cherts. The pyrite-chert banding is apparently caused by the sulfurisation of the iron minerals present in banded ferruginous cherts. Chalcopyrite is replaced by chalcocite and bornite along grain boundaries and fractures. The mineral tennantite appears to replace arsenopyrite.

\section{Paragenesis and Origin of the SulPhide Ores}

From the study of the textures and the mutual relationship existing between the various ore minerals it is inferred that the minerals like pyrrhotite, chalcopyrite, pyrite, cobaltite, sphalerite and arsenopyrite are primary, since they occur either as euhedral crystals with mutual boundary relations or occur as host minerals in which secondary minerals are housed. Chalcopyrite and pyrrhotite in sphalerite and stromyerite in chalcopyrite, tennantite in arsenopyrite and bornite and chalcocite in chalcopyrite are secondary since they clearly show indications of either replacement or exsolution.

Based on the textures the following paragenetic scheme for the sulphide ore minerals is proposed.

$\because$ The presence of mineral assemblage like pyrite-arsenopyrite-pyrrhotite suggests that the primary minerals are formed below $491^{\circ} \mathrm{C}$. as this assemblage is considered to be unstable above this temperature (Clark, 1960). Further the presence of exsolution textures particularly sphalerite-chalco- 
pyrite and sphalerite-pyrrhotite indicate the temperature of formation to range from $350^{\circ}$ to $500^{\circ} \mathrm{C}$. (Edward, 1954).

TABLE II

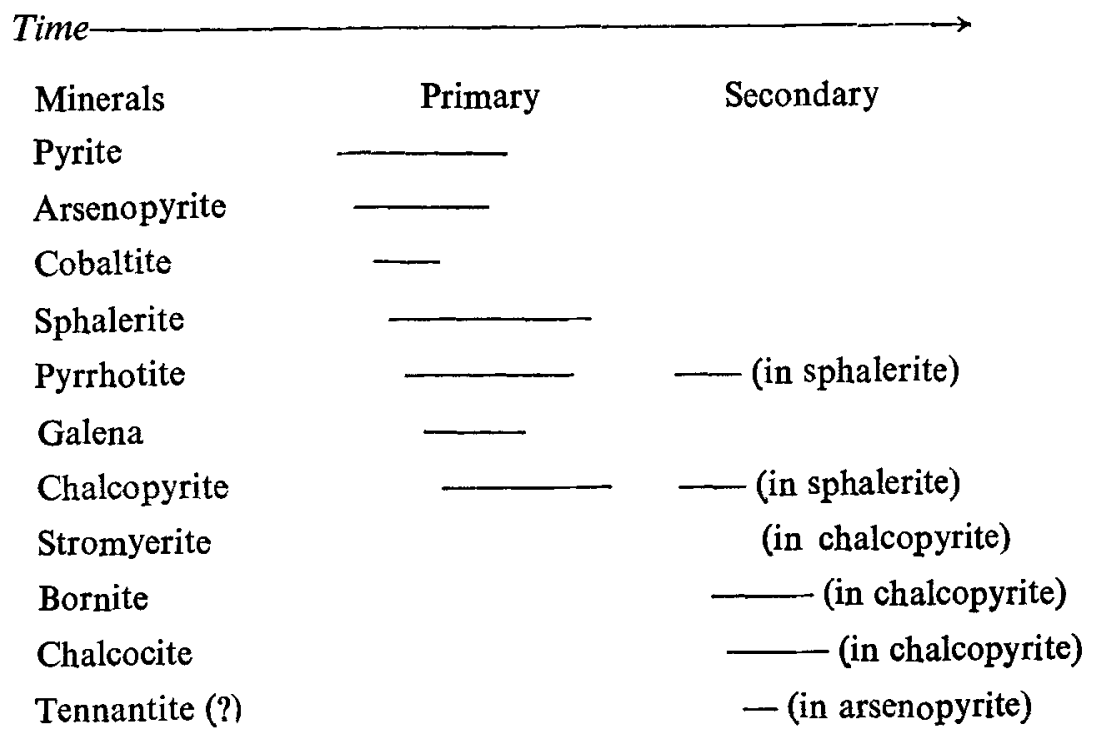

Bagchi (1970) has suggested sedimentary-syngenetic origin to pyrrhotite and pyrite recording the presence of slump and load-cast structures. $\mathrm{He}$ has proposed hydrothermal origin for the other sulphide ore minerals. The authors have also noted the presence of structures indicative of sedimentary origin. The sulphide ores particularly pyrite occurs in all the lithofacies-that is they are seen in chert bands, in trap rocks and in schistose rocks as bands, veins and veinlets. It is difficult to explain how through a sedimentary-syngenetic origin this mineral can occur in such disconnected manner in various lithotypes. The sedimentary structures like banding exhibited by pyritic cherts in this area can be explained through the process of "sulfurization" of the banded ferruginous cherts, where hydrothermal fluids containing $\mathrm{H}_{2} \mathrm{~S}$ or divalent sulphur can convert ferrous minerals into pyrite without altering the original texture or structures. Lovering (1963) has indicated that minerals formed through such a process are not to be considered as syngenetic in the strict sense of the term. He has suggested the name "diplogenetic" for such ores of dual origin. The authors are therefore inclined to believe that the entire sulphide ore mineralisation in Ingaldhal area has been brought about by hydrothermal processes, the pyrite ores exhibiting the sedimentary features being diplogenetic. 


\section{ACKNOWLEDGEMENT}

The authors sincerely thank Dr. B. P. Radhakrishna, Director, Department of Mines and Geology, for the encouragement he has given to take up this work and for giving permission to collect the samples in Ingaldhal copper mines. One of the authors (A. M. P.) thanks the C.S.I.R. for providing a Fellowship to undertake this research.

\section{REFERENCES}

1. Bagchi

2. Brett, R.

3. Cheney, E, S. and Lange, I. $\mathrm{M}$.

4. Clark, L. A.

5. Edward, A. B.

6. Lovering, T.S.

7. Radhakrishna, B. P.
.. Abstract, 57th Session, Ind. Sci. Cong., 1970.

.. "Experimental data from the system on Cu-Fe-S and their bearing on exsolution in ores," Eco. Geol., 1964, 59, 1241-69.

Evidence of Sulphurization and Origin of Some of SudburyType Ores, Min. Dept., 1967, pp. 80-94.

.. "The Fe-As-S system: phase relation and application," Eco. Geol., 1960, pp. 1345-81.

.. Textures of Ore Minerals and Their Significance. Aust. Inst. Min. Met.., Meibourne, 1954.

.. "Epigenetic, diplogenetic, syngenetic and lithogenetic deposits," Eco. Geol., 1963, pp. 315-31.

.. Copper in Mysore, 1967. 


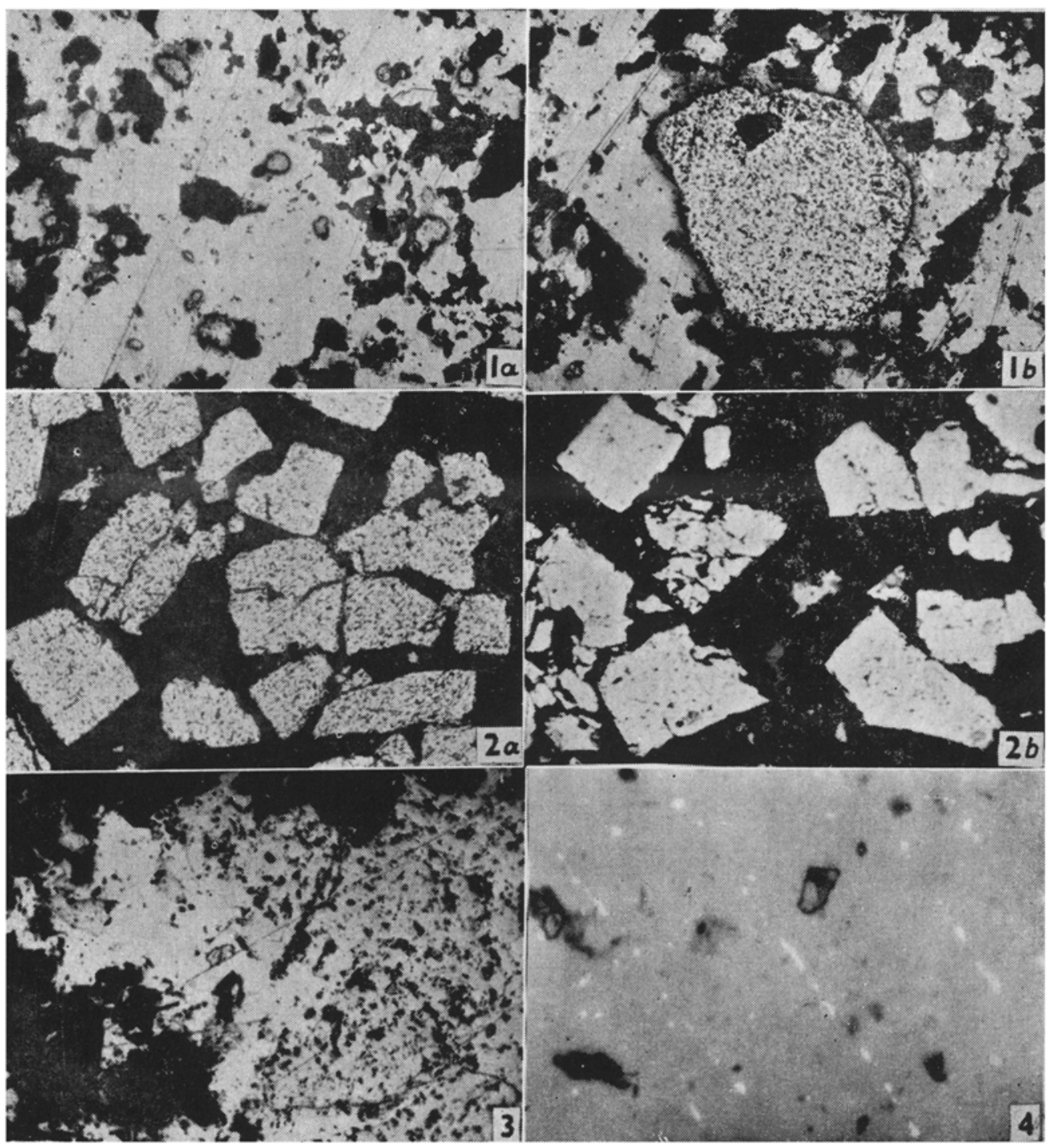

Fig. 1 a. Inclusion Texture: Rounded grains of cobaltite in chalcopyrite, $\times 80$.

Fig. 1 b. Inclusion Texture: Rounded pyrite grain in chalcopyrite, $\times 80$.

FIG. $2 a$. Panidiomorphic Texture: Euhedral and subhedral crystals of pyrite in chert, $\times 50$.

FIG. $2 b$. Panidiomorphic Texture: Euhedral and subhedral crystals of arsenopyrite in chert,

FIG. 3. Mutual Boundary Texture: Chalcopyrite (dark grey) and pyrrhotite (light grey) showing FiG. 4. Exsolution Texture: Globules and strings of chalcopyrite (light grey) in sphalerite
(dark grey), $\times 1,260$. 